\title{
Apple Grower Research and Extension Needs for Craft Cider
}

\author{
Marcia R. Ostrom ${ }^{1}$, David S. Conner ${ }^{2}$, Heleene Tambet ${ }^{1}$, \\ Katherine Selting Smith ${ }^{1}$, J. Robert Sirrine ${ }^{3}$, Philip H. Howard ${ }^{4}$, \\ and Michelle Miller ${ }^{5}$
}

AdDITIONAL INDEX wORDs. artisanal beverage, hard cider, Malus domestica, Michigan, terroir, Vermont, Washington, Wisconsin

Summary. Hard cider is an important and growing part of the U.S. beverage market. Previous research suggests there is an opportunity for growers interested in selling locally grown cider-specific apple (Malus domestica) varieties. However, cider apple growers face production, distribution, and marketing challenges. This article fills a gap in the literature using survey data from four states. We find that growers are interested in expanding cider apple production to supply local craft cider makers, but may be constrained by gaps in current production information, such as how to grow cider varieties. Uncertainty about the regional suitability of different varieties, disease management, and the willingness of cider makers to pay a premium for cider apple production constitute significant concerns. Survey respondents most commonly requested information on horticultural qualities of varieties and disease management. Top marketing needs include the ability to garner premium prices. A regional "terroir" approach to cider marketing holds promise.

$\mathrm{H}$ ard cider made from apples (Malus domestica) is an important and growing part of the U.S. beverage market. Sales increased by $\approx 50 \%$ annually between 2009 and 2014 (Petrillo, 2014). Global sales were estimated at $\$ 4.34$ billion in 2018 and are projected to rise to $\$ 5.43$ billion by 2026 (Fior Markets, 2020). At

Received for publication 1 Apr. 2021. Accepted for publication 20 Dec. 2021.

Published online 8 February 2022.

${ }^{1}$ School of Environment and Food Systems Program, Washington State University, PO Box 642812, Pullman, WA 99164

${ }^{2}$ Department of Community Development and Applied Economics, University of Vermont, 205H Morrill Hall, 146 University Place, Burlington, VT 05405

${ }^{3}$ Michigan State University Extension, 8527 E Government Center Drive, Suttons Bay, MI 49682

${ }^{4}$ Department of Community Sustainability, Michigan State University, Natural Resources Building, 480 Wilson Road, Room 316, East Lansing, MI 48824

${ }^{5}$ Center for Integrated Agricultural Systems, College of Agricultural and Life Sciences, University of Wisconsin-Madison, 1535 Observatory Drive, Madison, WI 53706

This work was supported by the Agriculture and Food Research Initiative of the U.S. Department of Agriculture, National Institute of Food and Agriculture under award no. 2018-68006-28105.

M.R.O. is the corresponding author. E-mail: mrostrom@ wsu.edu.

This is an open access article distributed under the CC BY-NC-ND license (https://creativecommons. org/licenses/by-nc-nd/4.0/).

https://doi.org/10.21273/HORTTECH04827-21 the Alcohol and Tobacco Tax and Trade Bureau (U.S. Department of the Treasury, 2020), cider is regulated as wine, and sales statistics are offered by gallons of cider on the market. In 2020, $98.7 \%$ of cider was bottled rather than sold in bulk. Counter to overall trends, the U.S. Department of the Treasury (2020) reported a sales decrease in taxable bottled cider sales in 2020 of 42.4 million gal compared with 49 million gal in 2019-a decrease of 6.6 million gal. At the same time, sales in cans are expected provide a notable area of growth opportunity (Singh, 2018). Recent growth is also concentrated among regional/local brands (Brager, 2019).

The ways in which consumers define concepts such as local and regional are poorly understood, and some research has indicated that state boundaries or perceived relationships with cideries may be more important than geographic distance in preferences for hard cider (Farris et al., 2019). With this growth comes the ongoing need for product differentiation in an increasingly competitive marketplace. Many cideries operate their own orchards to produce cider apples. Other cideries have expressed strong interest in sourcing apples locally, but many barriers around pricing and market access prevent this (Becot et al., 2016). We discuss survey data collected from orchardists from four U.S. states (Michigan, Vermont, Washington, and Wisconsin) with significant apple and cider-making industries. The research is part of a multistate project intended to improve the viability and competitiveness of small and medium-size orchards through collaborative, value-added market development.

\section{Opportunities and barriers to growth}

Previous literature (Becot et al., 2016) suggests that many cideries are planning to expand operations, which will further increase demand for local apples. Because it can take 6 years or more to harvest commercial quantities from a new orchard planting, the lag may create farmer challenges when assessing and responding to demand. In Vermont, all eight cideries surveyed by Becot et al. (2016) planned to expand their operations in the next 5 years. The vast majority also stated it was important $(25 \%)$ or very important $(62 \%)$ to source apples from in-state orchards, with $87 \%$ also wanting apples from the New England region. These results are similar to those in other regions and nationally. Gottschalk et al. (2017) noted a lack of availability of cider-specific varieties in Michigan. Peck and Miles (2015) found that all but one operation participating in a national cider convention planned to increase cider production and had a strong interest in sourcing apples locally. In a study of cideries in the north-central United States, $80 \%$ were purchasing apples or fresh-pressed juice directly from orchards, rather than purchasing commodity apple juice concentrate (Raboin, 2017). Craft cider makers in New York and Pennsylvania most commonly use

\begin{tabular}{llll}
\hline $\begin{array}{l}\text { Units } \\
\text { To convert U.S. to SI, } \\
\text { multiply by }\end{array}$ & U.S. unit & SI unit & $\begin{array}{l}\text { To convert SI to U.S., } \\
\text { multiply by }\end{array}$ \\
\hline 0.4047 & acre(s) & ha & 2.4711 \\
3.7854 & gal & L & 0.2642 \\
0.4536 & lb & kg & 2.2046
\end{tabular}


apples they grow themselves, supplemented with purchased apples and juice, mainly from dessert apples and those sourced locally (Pashow and Mahr, 2018; Snyder, 2018). However, the vast majority of cider production (by volume) in the United States is made with juice from concentrate or by processing dessert apples, not cider apples (Miles et al., 2020). Other studies posit the limited supply of specialty cider apple varieties as a significant barrier to cidery expansion (Galinato et al., 2016; Raboin, 2017).

\section{Production challenges}

These results suggest a latent demand for locally grown cider-specific apple varieties. However, as detailed by many (Merwin, 2015; Miles et al., 2020; Pashow and Mahr, 2018; Peck and Knickerbocker, 2018; Peck and Miles, 2015; Raboin, 2017), there are challenges in growing cider apples, in both production (variety selection, management, and economic viability), distribution, and marketing (pricing and market access). The subsequent paragraphs highlight the key challenges in the literature.

According to Merwin (2015), there are at least 1000 varieties of cider apples. These varieties are typically divided into four categories-sharps, sweets, bittersharps, and bittersweetsdepending on the composition of factors such as sugars, tannins, phenolics, aromatics, and acidity (Merwin, 2015). Apple variety, and concomitant flavor, play a large role in consumer taste and preference. Tozer et al. (2015) found that chemical composition, especially tannin content and sweetness, had positive and negative impacts, respectively, on consumer willingness to pay.

The U.S. Association of Cider Makers (2018) is concerned about how cider is described. To standardize language, they are developing a cider lexicon to guide makers in marketing their products. They developed USACM Cider Style Guidelines Version 2.0: Winter 2018 (U.S. Association of Cider Makers, 2018), which distinguishes between modern ciders, made primarily from dessert apples, and heritage ciders, made primarily from the fresh juice of multiuse or cider-specific bittersweet/bittersharp apples and heirloom varieties. In addition to standard ciders, the guide lists 10 specialty styles.
It is easier and less expensive to analyze cider chemistry in the laboratory than to gather flavor and other sensory data. In a multivariate analysis, Dawson et al. (2019) explored how laboratory measurements of variables such as $\mathrm{pH}$ and phenolics reflect the perceived taste of acidity and bitterness. Using single-source juice from 41 cider apple varieties, they found that tasters preferred higher perceived sweetness and acidity. The lowest rated ciders had high levels of titratable acidity, soluble solids concentration, and/or phenolics. Titratable acidity and $\mathrm{pH}$ correlated equally with perceived acidity, whereas soluble solids concentration correlated with bitterness and perceived strength (alcohol).

The literature details many challenges with cider apple production. Many of these varieties originated in England and Europe, and may not be well-adapted to heat and water stress in some major U.S. apple-growing regions (Merwin, 2015). Cider apples tend to bloom later, causing difficulties with thinning, and are prone to fruit drop (Merwin, 2015). Many cider varieties are susceptible to fire blight (Erwinia amylovora), and growers are fearful of bringing in nonresistant varieties to their orchards (Pashow and Mahr, 2018). Fire blight is also a large concern for dessert apple growers (Bradshaw and Hazelrigg, 2018). Last, most cider apples have low yields in comparison with modern varieties of dessert apples (Merwin, 2015). As Peck and Knickerbocker (2018, p. 10) summarize, "it is still unclear what the most productive and profitable cider apple cultivars will be in the U.S."

\section{Economic challenges}

The profitability of cider apples is uncertain. Growing cider apples is a 20 - to 30-year commitment (Miles et al., 2020). One study (Becot et al., 2018) suggests that lower production costs (e.g., spray, harvest, no need for grading or cosmetic perfection) for cider apple markets may improve any orchard's net present value over time. Other studies (e.g., Peck and Knickerbocker, 2018) have found a very wide range of economic outcomes, with net present value outcomes varying by a factor of six. There is a trade-off of risk with high-input and high-density production, with these systems presenting higher costs and potentially greater returns (Peck and Knickerbocker, 2018). Vertically integrated orchards may have an advantage in only needing to cover the costs of the apples and having the ability to add value through cider production (Peck and Knickerbocker, 2018), but this may not be practical to meet the needs of all orchards or all cideries. Low yields combined with high costs associated with fruit hobble profitability.

Cider apples bring marketing challenges and opportunities as well. As discussed, many studies document a cidery demand for local apples. Cideries in the Lake Champlain region (Vermont, New York, and Quebec) expressed a strong demand for local apples, citing the opportunity for collaboration in apple procurement and marketing efforts to achieve quality control, educate consumers, combat the threat of low-quality cider from elsewhere, and create economic development opportunities (Fabien-Ouellet and Conner, 2018). A major barrier, however, is pricing. There is a large gap in the prices that orchards wish to receive and cideries wish to pay-a difference as great as $\$ 5.45 /$ 40 -lb bushel (Becot et al., 2016). Furthermore, orchards are reluctant to invest in producing specialty cider apples for which they have no other market and bear the risk if cideries decline to buy them (Becot et al., 2016). On the other hand, producing both apples and cider may be seen as a way to spread the costs and benefits across the business, as seen in the percent of cideries that grow their own (integrated) vs. participate in a coordinated supply chain.

There is significant interest in regional marketing approaches that communicate terroir, as is commonly used with wines. According to the U.S. Department of the Treasury (2020), there are 252 American Viticultural Areas in the United States, including 22 in the study area. However, this designation system used by makers of grape (Vitis vinifera) wines is currently off-limits to makers of fruit wines. Cideries are required to label appellation of origin if the product label includes a varietal designation. If the cider label lists a state of origin, not less than $75 \%$ of the fruit used must be from that state. If fruit is sourced from multiple states, all states must be listed on the label. 
Growing cider apples for local cideries has potential, but comes with a set of production and marketing risks, with presumed additional uncertainty in the bar and restaurant industry resulting from the coronavirus disease 2019 pandemic. Given the opportunity, stakeholders have called for greater research and extension assistance to guide efforts to increase cider apple production, reduce risks to growers, and coordinate supply chains for mutual benefit (Peck and Miles, 2015; Raboin, 2017). A key gap in the literature is the perspective of growers. There is a lack of understanding of the experiences, perceptions, strategies, and informational needs expressed by the growers themselves. Our research intends to fill that gap. We report the results of a cider apple grower survey from four states, providing firsthand accounts of the farmers' perspectives on growing and marketing cider apples. Questions focus on their current practices, future plans, motivations, challenges, and resource needs.

\section{Materials and methods}

Survey DeVelopment. A grower survey draft was developed collaboratively by the four-state research team and revised with the project stakeholder advisory committee, made up of 11 growers, cider makers, and cider industry professionals. Recommendations from the advisory committee were to focus specifically on cider apple production, rather than cider pear production or general challenges with apple production. The committee also suggested a minimum threshold of 0.25 acre of apple production for cider making to be eligible to participate in the survey. The survey spanned growing, marketing, and business considerations for cider apples, as well as informational and extension needs. The survey instrument was constructed in an online survey platform (Qualtrics; Qualtrics International, Provo, UT/Seattle, WA) for online distribution following the tailored design method of Dillman et al. (2014). We pilot-tested the online survey with three cider apple growers for clarity and validity. They suggested reductions in length and a time estimate for the cover letter.

Survey implementation. To build our distribution list, the research team attempted to identify all cider apple growers in each state through extension lists, cider association grower lists, and interviews with key informants. When compiled, our final list included 95 unique orchards across the four states. After pilot testing, the survey was implemented online in English via Qualtrics and included the initial invitation and three reminders. Additional support was offered to assist with surveys by phone and/or in Spanish. The initial survey period spanned 21 Mar. to 1 June 2019, after which the project team recognized that some established orchards had not completed the survey, likely because of the timing during the growing season. The survey was reopened on 3 Dec. 2019 and closed 1 Feb. 2020. The first two questions of the survey were intended to filter out growers that do not grow at least 0.25 acre of apple trees specifically for the purpose of ineligible growers $(\mathrm{n}=5)$ and incorrect addresses $(\mathrm{n}=7)$ we had an adjusted response rate of $58 \%$ ( 48 of 83 ). Descriptive, frequency, and bivariate analyses were conducted on the dataset. Bivariate analysis focused on the marketing needs and information use of farms of different making hard cider. After removing the

scales (broken down into three categories by annual sales income $(<\$ 50,000$, between $\$ 50,000$ and $\$ 350,000$, and $>\$ 350,000)$ and by state.

\section{Results}

RESPONDENT CHARACTERISTICS. Our sample came from four states, with the greatest number from Washington $(\mathrm{n}=16)$, followed by Michigan $(\mathrm{n}=$ 15), Wisconsin $(\mathrm{n}=7)$, and Vermont $(\mathrm{n}=6)$. Although cider apple growers are not a distinct category, according to the 2017 Census of Agriculture (U.S. Department of Agriculture, 2017), Washington has 2522 apple farms, Michigan has 1551, Wisconsin has 1076, and Vermont has 343. The orchard size of our respondents ranged from less than 1 to 275 acres (median, 12 acres); apple cultivation area ranged from 0.25 to 80 acres (median, 4 acres). The mean share of total orchar acreage in cider apples was $60 \%$. As shown in Table 1 , the categories with the greatest number of responders were more than 60 years old, and farm incomes earned between $\$ 10,000$ and $\$ 50,000$ annually. The majority of

Table 1. Demographic characteristics of cider apple growers responding to an online survey conducted in Michigan, Vermont, Washington, and Wisconsin in 2019-20.

\begin{tabular}{|c|c|c|}
\hline Demographic characteristics & $\begin{array}{c}\text { Proportion of } \\
\text { respondents (\%) }\end{array}$ & Responses (no.) \\
\hline \multicolumn{3}{|l|}{ Age (years) $(\mathrm{N}=37)$} \\
\hline $30-39$ & 13.5 & 5 \\
\hline $40-49$ & 16.2 & 6 \\
\hline $50-59$ & 24.3 & 9 \\
\hline $60+$ & 46.0 & 17 \\
\hline \multicolumn{3}{|l|}{$\operatorname{Race}(\mathrm{N}=35)$} \\
\hline White & 94.3 & 33 \\
\hline Prefer not to answer & 5.7 & 2 \\
\hline \multicolumn{3}{|l|}{ Gender $(\mathrm{N}=36)$} \\
\hline Male & 80.6 & 29 \\
\hline Female & 11.1 & 4 \\
\hline Prefer not to answer & 8.3 & 3 \\
\hline \multicolumn{3}{|l|}{ Education $(\mathrm{N}=36)$} \\
\hline High school & 2.8 & 1 \\
\hline Some college, no degree & 8.3 & 3 \\
\hline Associate's degree & 5.6 & 2 \\
\hline Bachelor's degree & 61.1 & 22 \\
\hline Graduate degree & 22.2 & 8 \\
\hline \multicolumn{3}{|l|}{ Total farm income $(\mathrm{N}=36)$} \\
\hline$<\$ 10,000$ & 11.1 & 4 \\
\hline$\$ 10,000-\$ 50,000$ & 27.8 & 10 \\
\hline$\$ 50,000-\$ 150,000$ & 16.7 & 6 \\
\hline$\$ 150,000-\$ 350,000$ & 8.3 & 3 \\
\hline$\$ 350,000-\$ 1,000,000$ & 13.9 & 5 \\
\hline$>\$ 1,000,000$ & 22.2 & 8 \\
\hline
\end{tabular}


Table 2. Distribution of cider apple grower responses to the question "How do you market your apples for cider?" based on the percentage of growers using each marketing channel as part of an online survey conducted in Michigan, Vermont, Washington, and Wisconsin in 2019-20 $(\mathrm{N}=38)$.

Marketing channel Respondents stating they used each marketing channel (\%)

Keep for own cider production 68

Direct to cider maker 47

On-farm sales 32

Certified organic

16

Farmers' market

8

Distilleries

Through a distributor

Packing house

Barter/trade

respondents were white, male, and held a bachelor's degree or graduate degree.

UNIVARIATE ANALYSIS. On average, $60.5 \%$ of varieties grown by these orchardists for use in cider making are cider varieties, with the rest being dessert varieties (respondents could choose more than one response). They grow a diversity of types of cider apples; the majority of respondents reported growing bittersweets, bittersharps, sweets, sharps, and other varieties. The three most common sources of cider varieties are nurseries (72\%), other growers $(49 \%)$, and heritage (unmanaged) orchards (41\%).

The most common marketing channel (Table 2) for cider apples is for growers to use them for their own cider production $(68 \%)$, followed by direct-to-cider maker (47\%) and onfarm sales $(32 \%)$.

The results in Table 3 show that respondents believe local cider-specific apples are important for meeting strong consumer demand for craft cider. When asked about current and future prospects for cider apples, the two statements that garnered the strongest agreement were "Using cider-specific varieties is important for the growth of the craft cider industry" ( $86 \%$ agree or strongly agree) and "It is important for craft ciders to be associated with a particular region $(83 \%$ agree or strongly agree). The majority of respondents are members of a cider association, most commonly at the state or national level.

Future Plans, MOTIVATIONS, CHALLENGES, AND RESOURCE NEEDS. The majority of growers (53\%) plan to increase production in the next
The greatest production challenges reported by grower respondents, as judged by the percentage who rated them as "very challenging," are biennial fruiting and bloom management, and fire blight management (each rated as very challenging by more than $35 \%$ of respondents), followed by the high costs of production and pest/disease management (19\%). The least challenging aspects are access to varieties and postharvest handling (Table 5 ).

The greatest barriers to marketing cider apples (Fig. 2) were lack of consumer awareness of differences in cider $(87 \%)$ and prices consumers are willing to pay for ciders $(53 \%)$.

When growers were asked which resources they need to increase cider apple production, the two most common responses were knowledge of horticultural qualities of cider varieties (69\%) and knowledge of regional adaptability of cider varieties (69\%), followed by better rootstock/varietal selections to reduce vulnerabilities (51\%). When asked about future needs for marketing cider apples, the most common response was stable relationships with cider makers $(66 \%)$ followed by better margins (47\%) (Fig. 3).

The final set of questions focused on perceived research needs and preferred information content and sources.

Table 3. Distribution of apple grower responses when asked to "rate your agreement with the following statements" about the cider market based on the percentage of respondents selecting each answer on a 4-point continuum from "strongly disagree" to "strongly agree" as part of an online survey conducted in Michigan, Vermont, Washington, and Wisconsin in 2019-20.

\begin{tabular}{|c|c|c|c|c|}
\hline \multirow[b]{2}{*}{ Statement about cider market } & \multicolumn{4}{|c|}{ Proportion of respondents (\%) } \\
\hline & $\begin{array}{l}\text { Strongly } \\
\text { disagree }\end{array}$ & $\begin{array}{c}\text { Somewhat } \\
\text { disagree }\end{array}$ & $\begin{array}{c}\text { Somewhat } \\
\text { agree }\end{array}$ & $\begin{array}{c}\text { Strongly } \\
\text { agree }\end{array}$ \\
\hline $\begin{array}{l}\text { I plan to expand my cider apple } \\
\text { operation }(\mathrm{N}=37)\end{array}$ & 8.1 & 21.6 & 40.5 & 29.7 \\
\hline $\begin{array}{l}\text { There is strong consumer demand } \\
\text { for hard cider }(\mathrm{N}=37)\end{array}$ & 0.0 & 43.2 & 54.1 & 2.7 \\
\hline $\begin{array}{l}\text { There is strong consumer demand } \\
\text { for craft ciders made from } \\
\text { cider-specific varieties }(\mathrm{N}=37)\end{array}$ & 13.5 & 13.5 & 59.5 & 13.5 \\
\hline $\begin{array}{l}\text { There is a reliable market for cider } \\
\text { apples }(\mathrm{N}=36)\end{array}$ & 5.6 & 36.1 & 47.2 & 11.1 \\
\hline $\begin{array}{l}\text { There is a reliable market for } \\
\text { organic cider apples }(\mathrm{N}=33)\end{array}$ & 33.3 & 21.2 & 39.4 & 6.1 \\
\hline $\begin{array}{l}\text { Using cider-specific varieties is } \\
\text { important for the growth of the } \\
\text { craft cider industry }(\mathrm{N}=36)\end{array}$ & 2.8 & 11.1 & 36.1 & 50.0 \\
\hline $\begin{array}{l}\text { It is important for craft ciders to } \\
\text { be associated with a particular } \\
\text { region }(\mathrm{N}=35)\end{array}$ & 11.4 & 5.7 & 60.0 & 22.9 \\
\hline
\end{tabular}




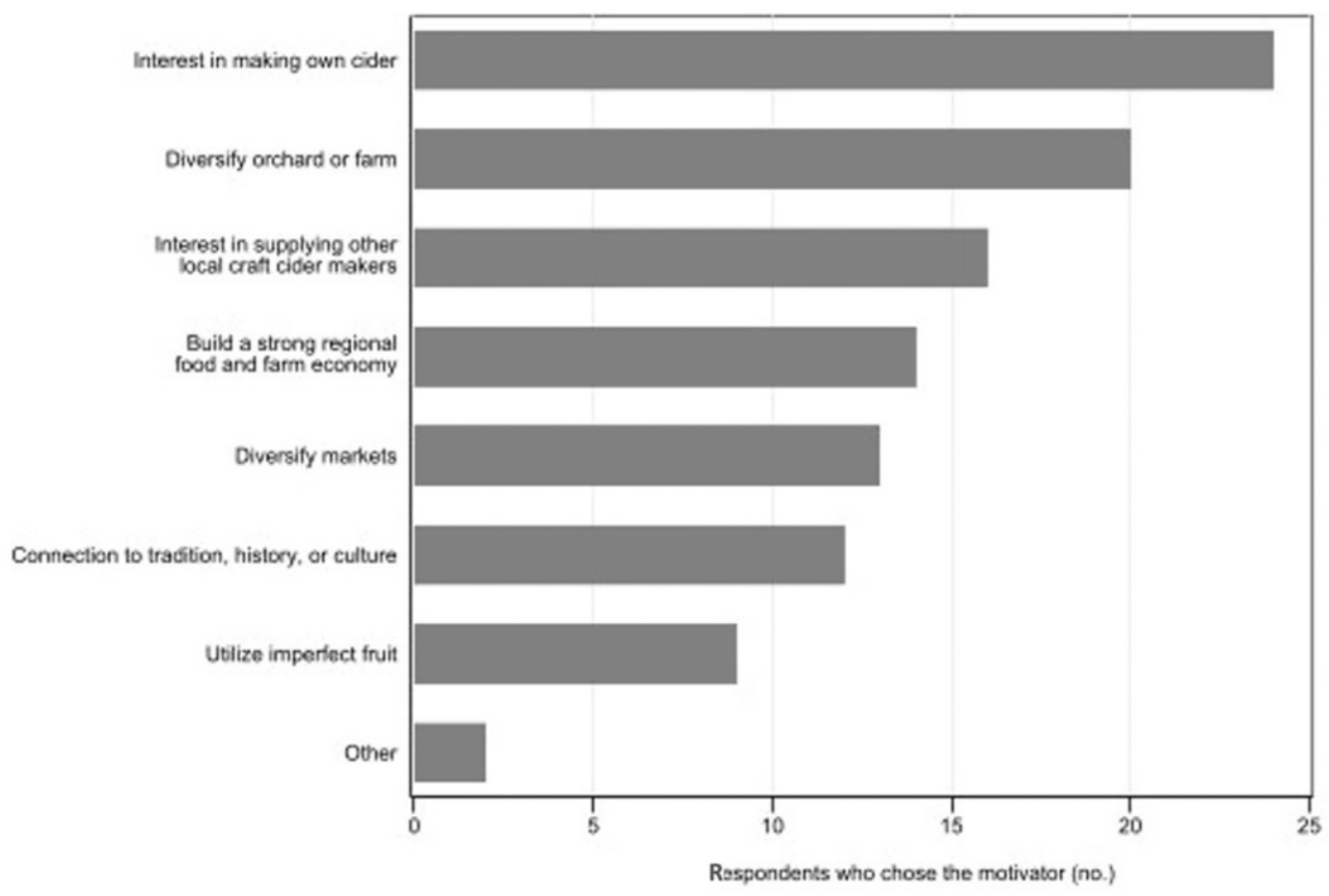

Fig. 1. Apple grower responses to the question, "What are your primary motivations for growing apples for cider?" based on the number of respondents selecting each option in an online survey conducted in Michigan, Vermont, Washington, and Wisconsin in 2019-20. Respondents were instructed to select "all that apply" ( $=39)$.

As shown in Fig. 4, the most frequently cited research need was understanding the regional suitability of varieties $(47 \%)$, followed by disease management $(45 \%)$, willingness of cideries to pay more $(45 \%)$, and willingness of consumers to pay more $(45 \%)$.

When asked how frequently they use various information sources, other

Table 4. Distribution of apple grower responses when asked to "rate the importance of the following factors in deciding which varieties of cider apples to grow" based on percentage of respondents selecting each answer on a 4-point continuum from "not important" to "very important" as part of an online survey conducted in Michigan, Vermont, Washington, and Wisconsin in 2019-20.

\begin{tabular}{lcccc}
\hline & \multicolumn{4}{c}{ Proportion of respondents (\%) } \\
\cline { 2 - 5 } $\begin{array}{l}\text { Factors influencing varietal } \\
\text { selection }\end{array}$ & $\begin{array}{c}\text { Not } \\
\text { important }\end{array}$ & $\begin{array}{c}\text { Less } \\
\text { important }\end{array}$ & $\begin{array}{c}\text { Somewhat } \\
\text { important }\end{array}$ & $\begin{array}{c}\text { Very } \\
\text { important }\end{array}$ \\
\hline $\begin{array}{l}\text { End product sensory } \\
\text { characteristics }(\mathrm{N}=36)\end{array}$ & 5.6 & 2.8 & 11.1 & 80.6 \\
$\begin{array}{l}\text { Apple chemistry (soluble solids } \\
\quad \text { concn, pH, phenolics, etc.) }\end{array}$ & 5.6 & 8.3 & 27.8 & 58.3 \\
$\quad(\mathrm{~N}=36)$ & 11.1 & 41.7 & 38.9 & 8.3 \\
$\begin{array}{l}\text { Varietal harvest dates }(\mathrm{N}=36) \\
\text { Market price for this variety }\end{array} \quad 38.9$ & 13.9 & 19.4 & 27.8 \\
$\quad(\mathrm{~N}=36)$ & 38.9 & 8.3 & 19.4 & 33.3 \\
$\begin{array}{l}\text { Market demand for this variety } \\
\quad(\mathrm{N}=36)\end{array}$ & 2.7 & 18.9 & 51.4 & 27.0 \\
$\begin{array}{l}\text { Yield }(\mathrm{N}=37) \\
\text { Disease susceptibility (N = 36) }\end{array}$ & 2.8 & 16.7 & 38.9 & 41.7 \\
Compatibility with organic & 50.0 & 11.1 & 13.9 & 25.0 \\
$\quad$ systems (N = 36) & & & & \\
\hline
\end{tabular}

cider apple growers were used most frequently $(70 \%)$, followed by a university or extension website $(69 \%)$. E-mail messages and bulletins from extension and industry were all used frequently by more than $50 \%$ of respondents (Table 6). However, only slightly more than half of respondents somewhat or strongly agreed that "my extension service provides me with support and resources for my cider apple production."

Bivariate anAlysis Results. As shown in Fig. 2, the largest growers were most likely to cite all marketing barriers except a lack of consumer awareness. In contrast, the smallest growers (sales less than \$50,000 annually) most commonly cited a lack of consumer awareness as a barrier. No other barrier garnered more than $50 \%$ of responses from small or medium growers.

As shown in Fig. 5, medium growers were least likely to cite a need for more stable relationships with cider makers. Large growers were most interested in contracts. The smallest growers were most interested in knowing prices for different varieties up front. In the final bivariate analysis, use of outreach information was compared across grower scale. As shown in Table 7, medium growers were the least likely to use other growers and extension resources as sources of information.

Vermont growers were especially interested in stable relationships with cider markets, whereas Michigan farmers sought better margins, and Wisconsin growers expressed an interest in identity preservation (Fig. 6). With respect to perceived barriers, 
Table 5. Distribution of apple grower responses when asked to "rate how challenging you find the following aspects of cider-specific apple production" based on percentage of respondents selecting each answer on a 4-point continuum from "not challenging" to "very challenging" as part of an online survey conducted in Michigan, Vermont, Washington, and Wisconsin in 2019-20.

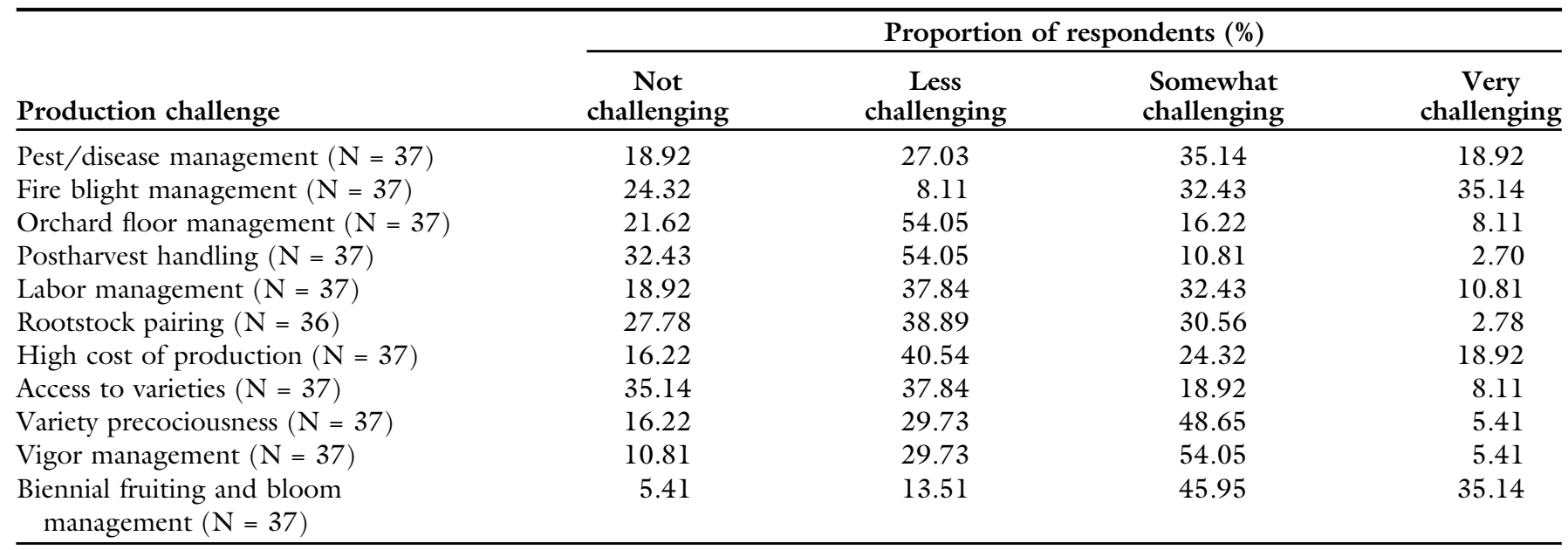

Fig. 7 shows that Vermont growers are concerned about lack of consumer awareness and willingness to pay, whereas Wisconsin growers expressed concern about consumer tastes and inadequate feedback. In comparing research and extension needs (Fig. 4), Vermont growers expressed a need for research and outreach on consumer willingness to pay, whereas Wisconsin growers emphasized research and extension needs for production and business management.

\section{Discussion}

This study explored some of the key issues surrounding cider apple production and marketing for craft ciders. Growers in our survey sample express a desire to expand production and meet the growing demand for local cider-specific apple varieties. More than two-thirds of our respondents say they are likely or very likely to expand operations in the next 5 years. Most believe local apples are important to the cider industry. Half strongly agree that using cider-specific varieties is important for the growth of the craft cider industry, and another $36 \%$ somewhat agree.

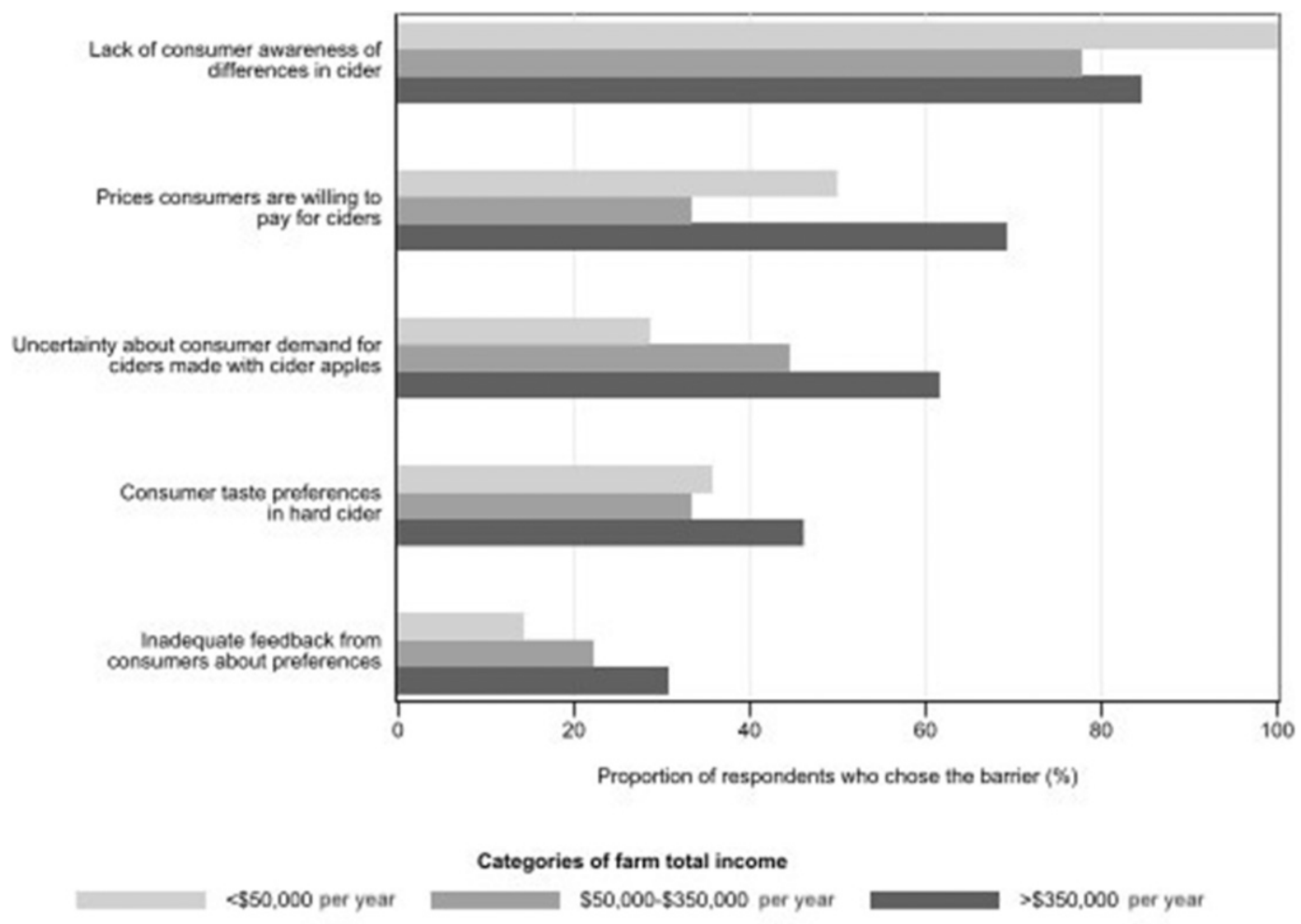

Fig. 2. Apple grower responses to the question, "What are barriers to the marketing of cider-specific apples?" in an online survey conducted in Michigan, Vermont, Washington, and Wisconsin in 2019-20 by farm income group. Respondents were instructed to select "all that apply" $(\mathrm{N}=36)$. 


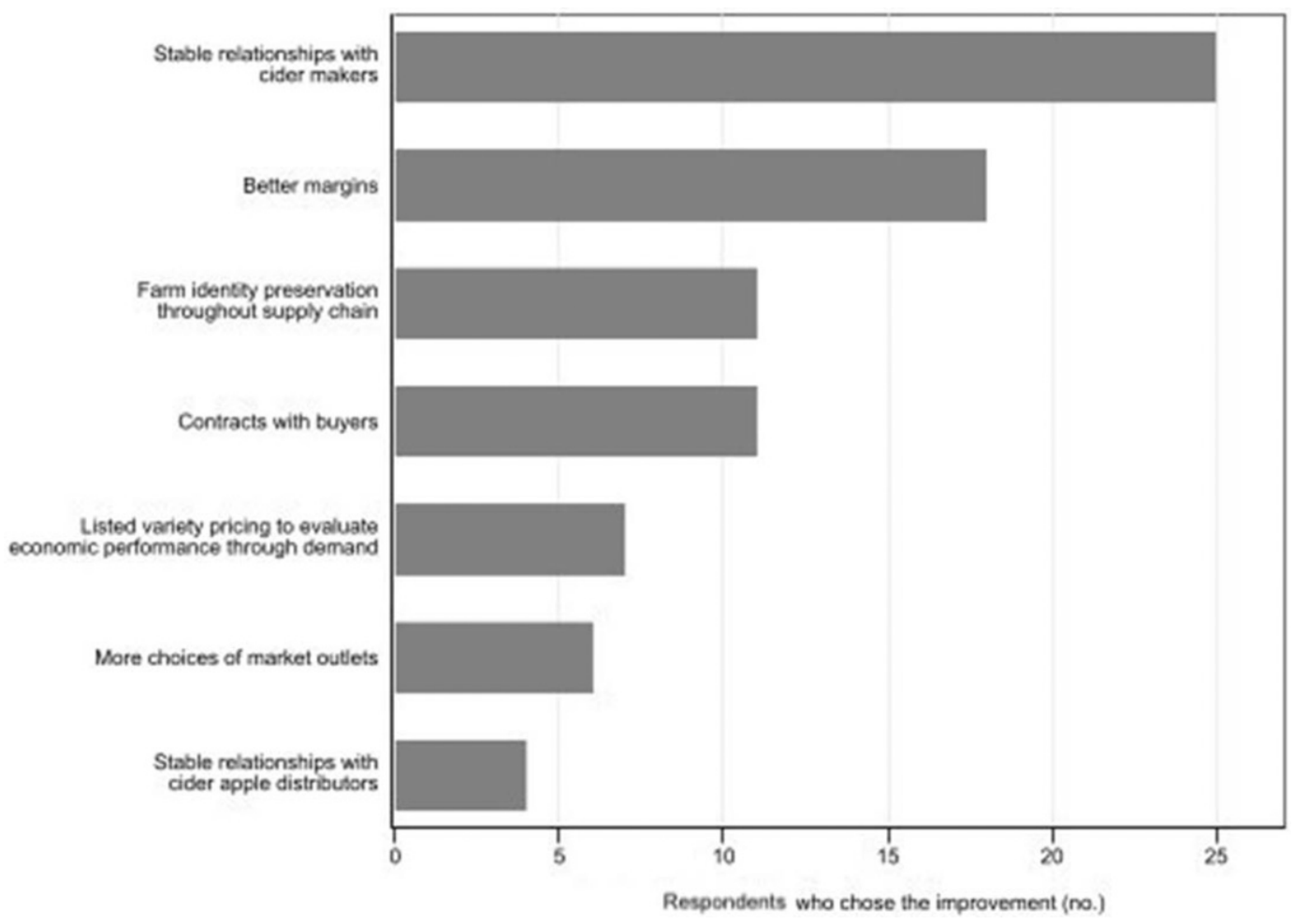

Fig. 3. Apple grower responses to the question, "What do orchardists need to improve their markets for cider-specific apples?" in an online survey conducted in Michigan, Vermont, Washington, and Wisconsin in 2019-20. Respondents were instructed to select "all that apply" $(\mathrm{N}=38)$.

Almost three-fourths agree there is strong consumer demand for craft ciders made from cider-specific varieties, and $86 \%$ find it important for craft ciders to be associated with a particular region. These growers are already using or selling apples locally; more than twothirds retain apples for their own cider production and nearly half sell directly to local cideries. Their motivations for growing cider apples are similar: supplying their own needs and supplying local needs. It is not stated where they would sell the increased volume from expansion, but presumably this action would increase local availability given their current market channels and stated motivations. The added production would likely consist of varieties that would be a good fit for cider production because, as seen in prior research (Merwin, 2015), these growers place the greatest importance on end-user sensory attributes and apple chemistry when they select cider apple varieties.

These growers experience many of the same risks and challenges as noted in previous literature (Merwin, 2015; Miles et al., 2020; Peck and Knickerbocker, 2018; Peck and Miles, 2015; Raboin, 2017). These growers identified biennialism and bloom management, and fire blight as the greatest production challenges (Bradshaw and Hazelrigg, 2018; Merwin, 2015; Pashow and Mahr, 2018). The greatest marketing challenges centered around a lack of certainty about demand, such as consumer awareness of differences and willingness to pay for cider made with cider apples.

Our findings are consistent with previous studies that call for greater research on these constraints to inform outreach to growers and information providers (Peck and Miles, 2015; Raboin, 2017). The greatest information needs these growers identify center around knowledge of horticultural qualities of varieties, their regional adaptability and availability, and disease management. The growers also identified a number of research and extension needs related to marketing. Marketing needs include building greater consumer awareness, a willingness for both cideries and consumers to pay more for high-quality cider, and a call for a regional "terroir" approach to cider marketing that emphasizes unique, place-specific qualities [the latter point echoes findings by Fabien-Ouellet and
Conner (2018)]. When asked how often they use technical assistance from various sources, the most popular source was other growers, followed by university or extension websites, and cider industry associations. Online decision-aid programs and personal visits from extension agents were used less frequently.

A strength of this research lies in its multistate approach and attention to a breadth of production and marketing issues. Its principal weakness is not knowing how representative our sample is because of the lack of previous research detailing the scale of this emerging sector. However, we made great efforts to locate and contact all craft cider apple growers in each of our four states. Although we tried to build a complete list of existing cider apple growers in each state, there are no formal lists of such growers. Thus, the completeness of our list-building, and the representativeness of our survey, are unclear. Regardless, we have not seen other attempts to hear from the range of cider apple growers in these states. A final future research direction is to measure these results on larger samples across the country. 


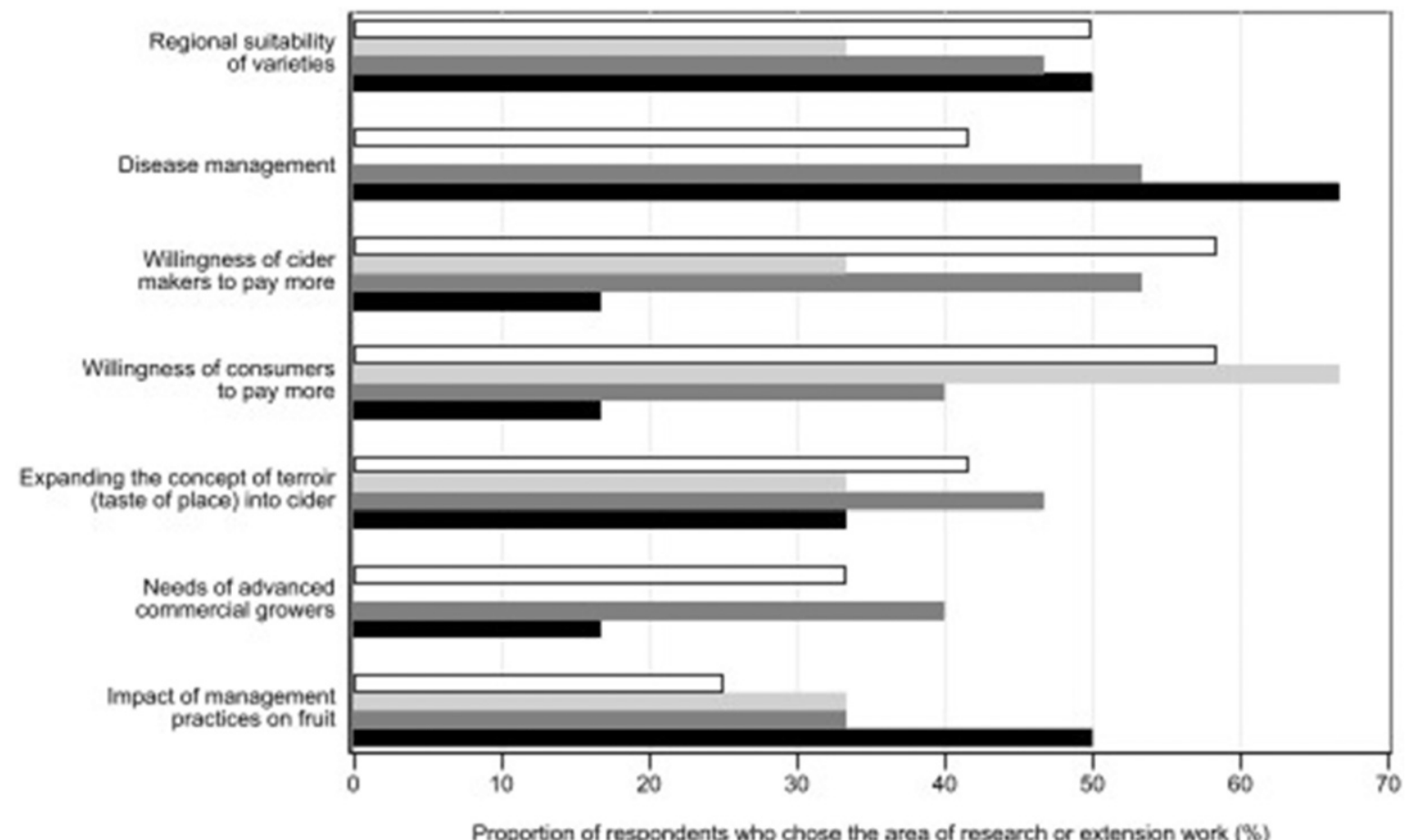

Proportion of respondents who chose the area of research or extension work (\%)

Locations by state

Vermont

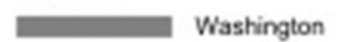

Wisconsin

Fig. 4. The most popular responses to the question, "What are your preferences for future research and extension work related to cider apple varieties?" by state in an online survey of cider apple growers in Michigan, Vermont, Washington, and Wisconsin in 2019-20. Respondents were instructed to select "all that apply" $(\mathrm{N}=36)$.

\section{Conclusion}

This study explored apple growers' perceptions and experiences around growing and marketing cider apple varieties. It fills a key gap in the literature

Table 6. Distribution of responses to the question, "How many times did you use the following information sources in the past year?" based on percentages of apple growers selecting each answer on a 3-point continuum from "not at all" to "multiple times" in an online survey conducted in Michigan, Vermont, Washington, and Wisconsin in 2019-20.

\begin{tabular}{lrrr} 
& \multicolumn{3}{c}{ Proportion of respondents (\%) } \\
\cline { 2 - 4 } Information source & $\begin{array}{c}\text { Not } \\
\text { at all }\end{array}$ & Once & $\begin{array}{c}\text { Multiple } \\
\text { times }\end{array}$ \\
\hline Other cider apple growers $(\mathrm{N}=33)$ & 12.1 & 18.2 & 69.7 \\
University or extension website $(\mathrm{N}=36)$ & 13.9 & 16.7 & 69.4 \\
E-mail from cider industry association $(\mathrm{N}=35)$ & 28.6 & 14.3 & 57.1 \\
E-mail from extension $(\mathrm{N}=34)$ & 29.4 & 17.7 & 52.9 \\
Extension bulletin, article or newsletter $(\mathrm{N}=34)$ & 41.2 & 5.9 & 52.9 \\
Cider industry association website $(\mathrm{N}=37)$ & 35.1 & 16.2 & 48.7 \\
Extension meeting, conference, or workshop $(\mathrm{N}=32)$ & 40.6 & 18.8 & 40.6 \\
Cider association meeting, conference, or & 30.3 & 33.3 & 36.4 \\
$\quad$ workshop $(\mathrm{N}=33)$ & & & \\
Extension office $(\mathrm{N}=31)$ & 54.8 & 12.9 & 32.3 \\
University decision-aid online program $(\mathrm{N}=33)$ & 75.8 & 3.0 & 21.2 \\
Extension agent visit to my farm $(\mathrm{N}=32)$ & 75.0 & 21.9 & 3.1 \\
\hline
\end{tabular}

by bringing real-world perspectives to many issues identified in previous studies. Specifically, we find that growers are interested in expanding cider varietal apple production, but this expansion may be constrained by gaps in current production and marketing information. Uncertainty about the regional suitability of different varieties, disease management, and the willingness of cider makers to pay for cider-specific apple production constitute significant concerns. Perceived market barriers differ by size of orchard. Small growers cite low consumer awareness of craft cider qualities whereas large growers cite all the other market barriers, but not consumer awareness.

These results suggest a number of implications for research and outreach. Important research priorities include greater availability and testing of regionally adapted cider apple varieties with properties suitable for high-quality cider. Managing disease, especially fire blight, is another important research need. On the marketing research side, growers want to understand more fully the demand for cider apple varieties on the part of cideries and consumers, and the prospects for regional collaboration and a "terroir" approach. 


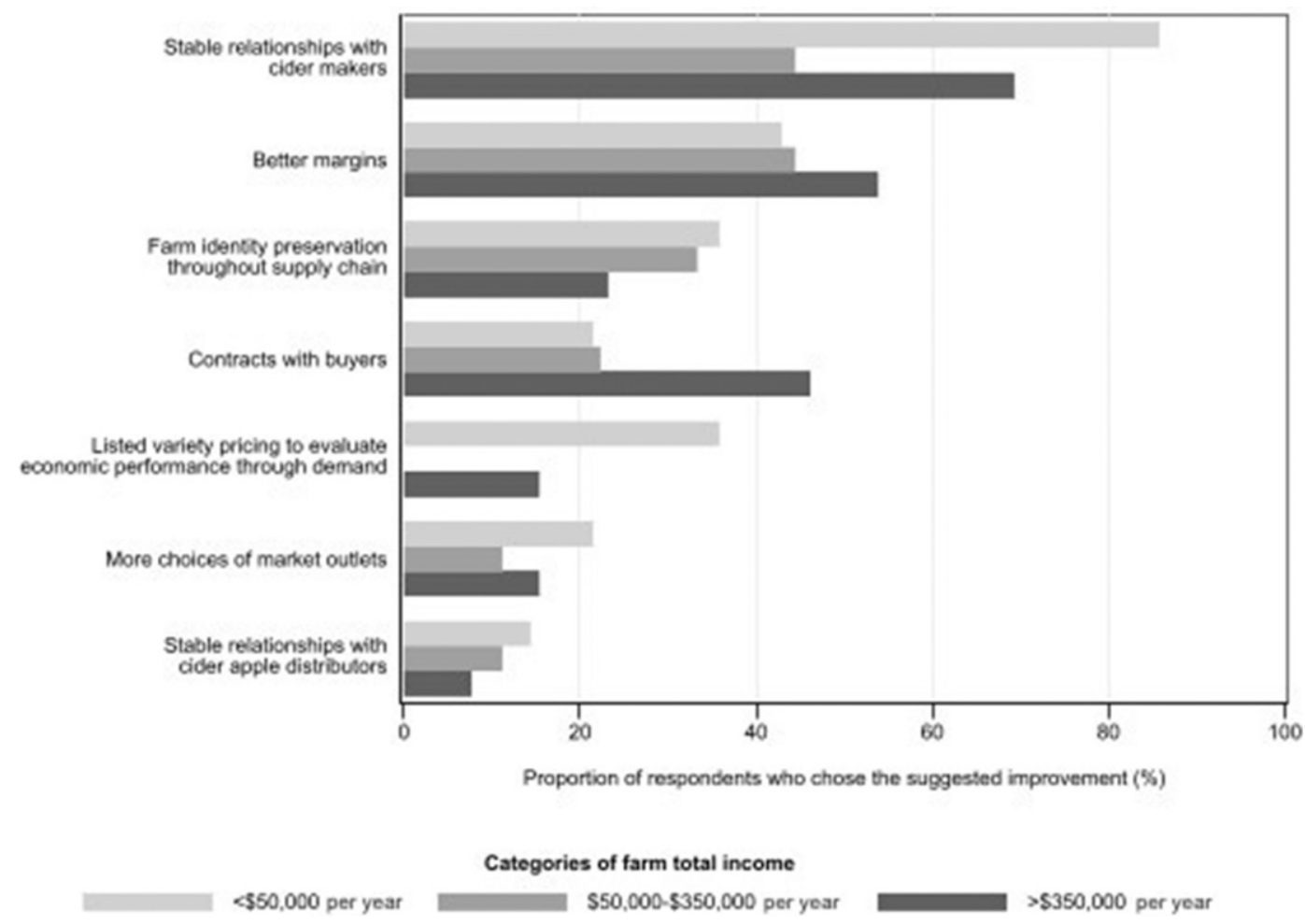

Fig. 5. Apple grower responses to the question, "What do orchardists need to improve their markets for cider-specific apples?" by farm income group in an online survey of cider apple growers in Michigan, Vermont, Washington, and Wisconsin in 2019-20. Respondents were instructed to select "all that apply" $(\mathrm{N}=36)$.

Outreach may be most effective by forming partnerships among growers, industry, and extension. Each has unique assets to contribute. Growers bring credibility and practical knowledge, industry brings financial resources and grower networks, and extension brings outreach expertise. Key avenues of activity include dissemination of knowledge of varieties, management tools, and marketing opportunities. These partnerships may be particularly effective at fostering the regional collaboration and organizational development needed to shape "terroir" and place-based or regional marketing efforts.

Based on the responses to our survey, different outreach strategies for farms of different scales may be explored and tested. For example, because larger growers were more interested in contracts and broader consumer education efforts, there may be an opportunity for them to collaborate on these efforts. Smaller growers may benefit from closer collaboration with cideries to create more stable and diversified markets and predictable pricing. Last, medium growers were less likely to use extension information sources such as bulletins, newsletters conferences, and workshops. This suggests a need to understand more completely the information preferences of medium growers.

Table 7. Percentage of apple cider growers who reported using an information source "multiple times" in the past year by income group in an online survey conducted in Michigan, Vermont, Washington, and Wisconsin in $2019-20$ ( $\mathrm{N}=34$ ).

\begin{tabular}{|c|c|c|c|c|}
\hline \multirow[b]{2}{*}{ Information source } & \multicolumn{4}{|c|}{ Proportion of respondents (\%) } \\
\hline & $<\$ 50,000$ & $\$ 50,000-\$ 350,000$ & $>\$ 350,000$ & $\begin{array}{c}\text { All income } \\
\text { groups combined }\end{array}$ \\
\hline University or extension website & 50 & 44 & 54 & 50 \\
\hline E-mail from cider industry association & 9 & 25 & 31 & 22 \\
\hline E-mail from extension & 42 & 50 & 69 & 55 \\
\hline Extension meeting, conference, or workshop & 50 & 38 & 69 & 55 \\
\hline Cider association meeting, conference, or workshop & 27 & 29 & 62 & 42 \\
\hline Extension office & 17 & 29 & 62 & 38 \\
\hline University decision-aid online program & 0 & 0 & 8 & 3 \\
\hline Extension agent visit to my farm & 67 & 71 & 77 & 72 \\
\hline
\end{tabular}




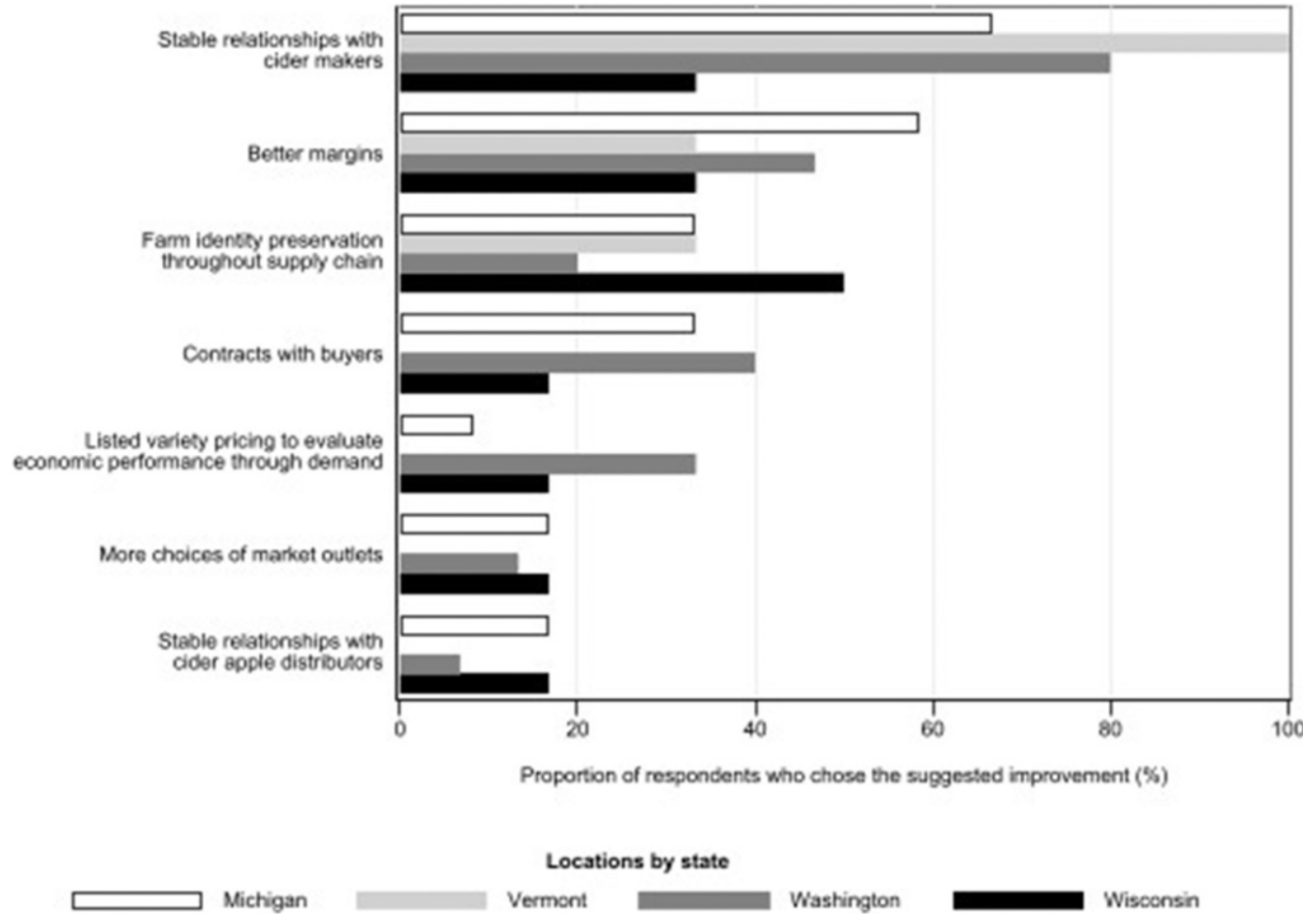

Fig. 6. Apple grower responses to the question, "What do orchardists need to improve their markets for cider-specific apples?" in an online survey of cider apple growers in Michigan, Vermont, Washington, and Wisconsin in 2019-20 by state. Respondents were instructed to select "all that apply" $(\mathrm{N}=36)$.

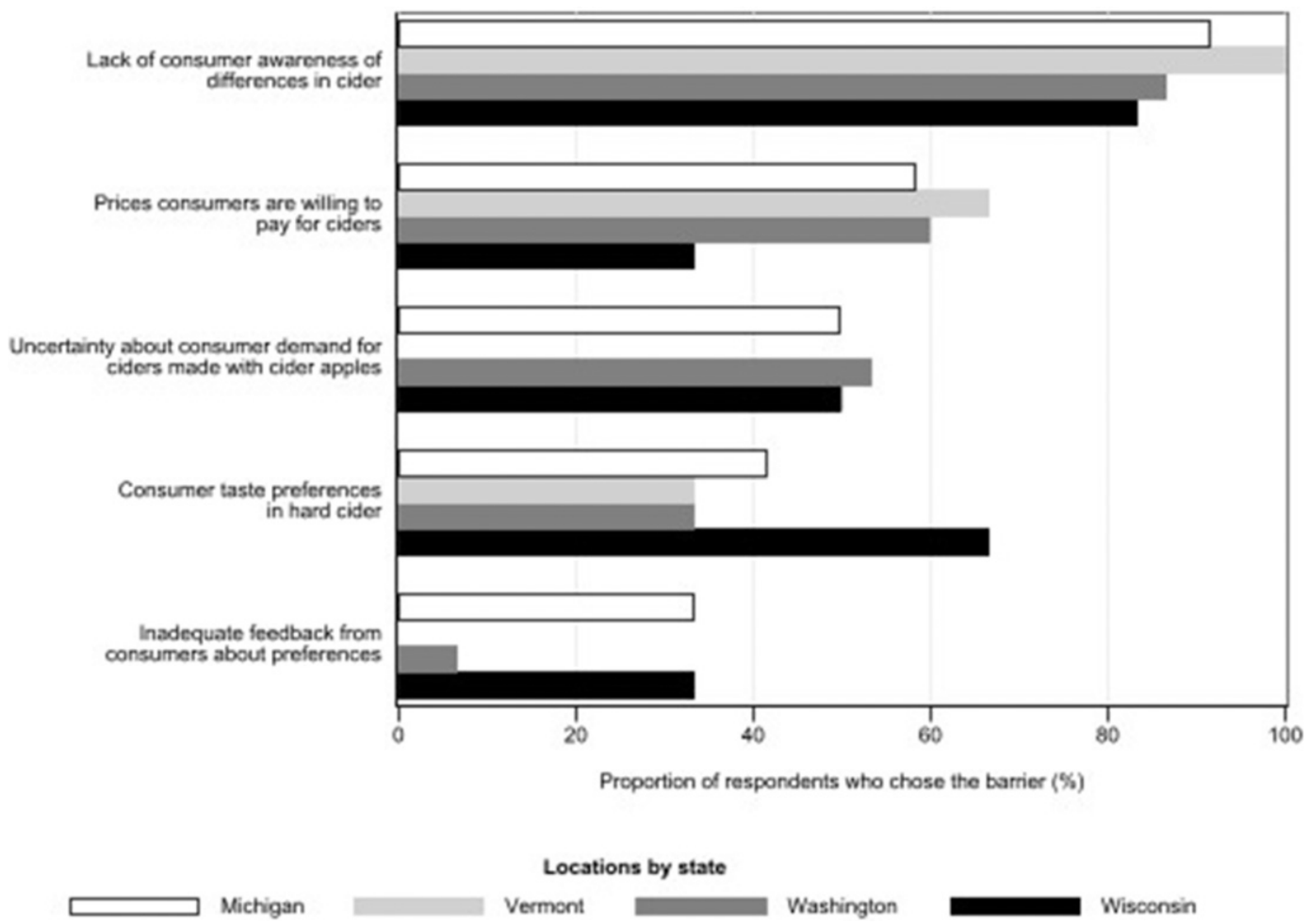

Fig. 7. Apple grower responses to the question, "What are barriers to the marketing of cider-specific apples?" in an online survey of cider apple growers in Michigan, Vermont, Washington, and Wisconsin in 2019-20 by state. Respondents were instructed to select "all that apply" $(\mathrm{N}=36)$. 


\section{Literature cited}

Becot, F., T. Bradshaw, and D. Conner. 2016. Apple market expansion through value-added hard cider production: Current production and prospects in Vermont. HortTechnology 26:220-229, https://doi. org/10.21273/HORTTECH.26.2.220.

Becot, F., T. Bradshaw, and D. Conner. 2018. Growing apples for the cider industry in the US northern climate of Vermont: Does the math add up? Acta Hort. 1205: 461-468, https://doi.org/10.17660/acta Hortic.2018.1205.56.

Bradshaw, T. and A. Hazelrigg. 2018. Status of IPM practice adoption in Vermont apple orchards in 2017. Univ. Vermont College Agr. Life Sci. Faculty Publ. 28. 30 May 2021. <https://scholar works.uvm.edu/calsfac $/ 28>$.

Brager, D. 2019. The cider rebound: Now let's keep it going. 12 June 2020. < https:// ciderassociation.org/wp-content/uploads/ 2019/02/Nielsen-Presn-at-CiderCon2019_2-7-2019.pdf>.

Dawson, J., M. Miller, M. Raboin, N. Smith, E. Voigt, C. Carusi, and R. McNair. 2019. Comparing apples to apples: Single-varietal hard apple cider testing. 12 June 2020. <https://www.cias. wisc.edu/comparing-apples-to-apples $/>$.

Dillman, D., J. Smyth, and L. Christian. 2014. Internet, phone, mail, and mixedmode surveys: The tailored design method. 4th ed. Wiley, Hoboken, NJ.

Fabien-Ouellet, N. and D. Conner. 2018. The identity crisis of hard cider. J. Food Res. 7(2):54-67, https://doi.org/10.5539/jfr. v7n2p54.

Farris, J., T. Malone, L. Robison, and N. Rothwell. 2019. Is "localness" about distance or relationships? Evidence from hard cider. J. Wine Econ. 14(3):252-273, https://doi.org/10.1017/jwe.2019.42.
Fior Markets. 2020. Cider market by product (apple flavored, fruit flavored, and perry), distribution channel, packaging, regions, global industry analysis, market size, share, growth, trends, and forecast 2019 to 2026. 7 May 2021. <https:// www.fiormarkets.com/report/cider-marketby-product-apple-flavored-fruit-flavored-407 145.html $>$.

Galinato, S., C. Miles, and T. Alexander. 2016. Feasibility of different harvest methods for cider apples: Case study for western Washington. Washington State Univ. Ext. TB32E. 12 June 2020. <https://pubs. extension.wsu.edu/feasibility-of-differentharvest-methods-for-cider-apples-casestudy-for-western-washington $>$.

Gottschalk, C., N. Rothwell, and S. van Nocker. 2017. Apple cultivars for production of hard cider in Michigan. Michigan State Univ. Ext. Bull. E3364. 30 May 2021. <https://www.canr.msu.edu/resources/ apple_cultivars_for_production_of_hard_ cider_in_michigan_e3364>.

Merwin, I. 2015. Growing apples for craft ciders. N.Y. Fruit Qrtly. 23(1):5-10.

Miles, C., T. Alexander, G. Peck, S. Galinato, C. Gottschalk, and S. van Nocker. 2020. Growing apples for hard cider production in the United States: Trends and research opportunities. HortTechnology 30:148-155, https://doi.org/10.21273/ HORTTECHO4488-19.

Pashow, L. and M. Mahr. 2018. Hard cider supply chain analysis. 30 May 2021. $<$ https://harvestny.cce.cornell.edu/ uploads/doc_48.pdf $>$.

Peck, G. and W. Knickerbocker. 2018. Economic case studies of cider apple orchards in New York State. Fruit Qrtly. 26(3):5-10.

Peck, G. and C. Miles. 2015. Assessing the production scale and research and extension needs of U.S. hard cider producers. J. Ext. 53:5FEAl0. 14 June 2020.
$<$ https://archives.joe.org/joe/2015 october/pdf/JOE_v53_5al0.pdf $>$.

Petrillo, N. 2014. Cider production in the United States. IBISWorld Ind. Rep. OD5335, IBISWorld, Melbourne, Australia.

Raboin, M. 2017. Hard cider in the north central region: Industry survey findings. 24 June 2020. <https://cias.webhosting. cals.wisc.edu/wp-content/uploads/sites/ 194/2017/07/cideerstudy071817web. pdf $>$.

Singh, S. 2018. Cider market by product (apple flavored, fruit flavored, and perry), distribution channel (on-trade and offtrade), and packaging (draught, cans, glass bottles, plastic bottles, and others): Global opportunity analysis and industry forecast, 2017-2023. 24 June 2020. <https://www.alliedmarketresearch.com/ cider-market $>$.

Snyder, C. 2018. Hard cider business benchmark survey. 30 May 2021. <https:// extension.psu.edu/hard-cider-businessbenchmark-survey $>$.

Tozer, P., S. Galinato, C. Ross, C. Miles, and J. McCluskey. 2015. Sensory analysis and willingness to pay for craft cider. J. Wine Econ. 10(3):314-328, https://doi. org/10.1017/jwe.2015.30.

U.S. Association of Cider Makers. 2018. USACM cider style guidelines version 2.0: Winter 2018. 28 June 2020. <https:// ciderassociation.org/wp-content/ uploads/2018/12/USACM-StyleGuidelines-V2p0.pdf $>$.

U.S. Department of Agriculture. 2017. 2017 Census of Agriculture, National Agricultural Statistics Service. 10 June 2017. <https://www.nass.usda.gov/AgCensus > .

U.S. Department of the Treasury. 2020. Cider resources. I May 2021. <https:// www.ttb.gov/cider/cider-resources $>$. 